\title{
Editorial: AABFJ Volume 10, Issue 4, 2016
}

\author{
Ciorstan Smark ${ }^{1}$ and Monir Mir ${ }^{2}$
}

The December 2016 issue of AABFJ carries articles from the areas of accounting, finance and financial planning and has published research papers based on various issues from Vietnam, India, Pakistan, China and Oman in addition to papers from Singapore and Australia and therefore upheld the journal's reputation and strength of promoting research from developing and emerging economies.

Accounting curriculums globally are mostly dictated by the professional accounting bodies and hence accounting educators do not try with too much experimentation with innovative and non-traditional teaching deliveries for the fear of violating accreditation requirements. The research of Wheaton, O'Connell and Yapa is an eye-opener for accounting educators globally. They investigated a non-traditional teaching delivery approach (inter-teaching which is normally used in teaching psychology courses) in teaching auditing in a university in Vietnam and found that the approach is more effective of enhancing accounting students' learning compared to the traditional 'teachers talk students listen' approach normally used in teaching accounting courses. With the fast progressing world of technological innovations, there is an urgent need for modernising accounting education meeting the contemporary needs of the various stakeholders. Wheaton, O'Connell and Yapa have provided evidence that inter-teaching may provide a promising approach in modernising accounting education.

Shoaib and Siddiqui (2016) have examined the long term adjustment of risk premiums and fundamental factors in the emerging stock markets of the South Asian region. This includes the markets of India, Pakistan and China and hence responded to AABFJ's call for more research involving the capital markets of developing and emerging economies. The capital markets of emerging and developing economies have got many specific characteristics (such as they are less liquid) not observed in the markets of developed economies and hence the findings based on research in developed economies may not be applicable to developing and emerging economies. While comparing the adjustments of risk premiums in the capital markets of China, India and Pakistan, interestingly Shoaib and Siddiqui (2016) observed that Chinese capital market is more efficient and matured than the capital markets of India and Pakistan. Further research may unearth why Chinese capital market, although less older than Indian and Pakistani capital markets, has become more efficient and matured than the Indian and Pakistani markets.

\footnotetext{
${ }^{1}$ University of Wollongong, Australia

${ }^{2}$ University of Canberra, Australia
} 
McLaren, Yeo and Sweet have provided evidence that the socio-economic and citizen welfare strategies and policies of a developed or emerging economy may be more smarter than many other developed economies. Normatively they have suggested that Australian home-ownership crises will get worse over the years and Australia could adopt Singaporean approach of public housing. The Singapore approach is less reliant on superannuation and inter-generational taxation for retirement benefits of the retirees, rather its public housing policy helps generating assets for the retirees and hence there is less pressures on the intergenerational taxation. It may be interesting to know empirically whether the Singaporean model is also applicable to developing economies where there are no superannuation type contributions in private sector employments.

Anderson, Clark, Ramsay and Shekhar have examined the behaviour and attitudes towards superannuation of 25-34 year old Australians. Their results suggest a notable lack of interest in, and engagement with issues related to their retirement planning. The research of Anderson, Clark, Ramsay and Shekhar is somehow reflecting the normative findings of McLaren, Yeo and Sweet (see above) who thinks that Australian retirees are already suffering from poverty due to less savings through their superannuation and with the notable lack of interest in managing the superannuation by the Gen Y as observed by Anderson, Clark, Ramsay and Shekhar, the economic situation of the retirees are go to be further worse in future. More research is needed to find out whether enhancing financial literacy of Australian Gen Y would change their attitudes positively towards superannuation saving.

Rounding out this issue, Mohammed has presented a case study on the financial health of a Raysut Cement Company SAOG and its subsidiaries in Oman applying Altman Z-score. Altaman Z-score is one of the most popular financial analysis tools extensively used by market analysts and lenders of various categories. With the implementation of 'new public management' philosophies in the public sectors of many developed and developing economies, these sectors behave like private sectors including the adoption of private accounting standards in the public sector. It would be interesting to investigate whether Altman Z-score could also be applied in public sector context in predicting bankruptcy.

\section{References}

Anderson, Malcolm; Clark, Martin; Ramsay, Ian; and Shekhar, Chander, Super Behaviour: A Note on Young Australian Adults' Engagement With Their Superannuation Accounts, Australasian Accounting, Business and Finance Journal, 10(4), 2016, 63-75. doi:10.14453/aabfj.v10i4.5 DOI http://dx.doi.org/10.14453/aabfj.v10i4.5

McLaren, John; Yeo, Allan; and Sweet, Michael, Australia is Facing a Housing Affordability Crisis: Is the Solution to this Problem the Singapore Model of Housing?, Australasian Accounting, Business and Finance Journal, 10(4), 2016, 43-62. doi:10.14453/aabfj.v10i4.4 DOI http://dx.doi.org/10.14453/aabfj.v10i4.4

Mohammed, Shariq, Bankruptcy Prediction by Using the Altman Z-score Model in Oman: A Case Study of Raysut Cement Company SAOG and its subsidiaries, Australasian Accounting, Business and Finance Journal, 10(4), 2016, 75-85. doi:10.14453/aabfj.v10i4.6 DOI http://dx.doi.org/10.14453/aabfj.v10i4.6

Shoaib, Adnan and Siddiqui, Muhammad Ayub, Long run Adjustment of Size, Value, Momentum and Growth Premium in Equity Returns: Evidence from South Asian Emerging Markets, Australasian Accounting, Business and Finance Journal, 10(4), 2016, 17-42. doi:10.14453/aabfj.v10i4.3 DOI http://dx.doi.org/10.14453/aabfj.v10i4.3

Wheaton, Mark; O'Connell, Brendan; and Yapa, Premasiri, Inter-teaching: Improving the Academic Performance of Auditing Students in Vietnam, Australasian Accounting, Business and Finance Journal, 10(4), 2016, 3-16. doi:10.14453/aabfj.v10i4.2 DOI http://dx.doi.org/10.14453/aabfj.v10i4.2 